\title{
Dokument
}

\section{Danske udfordringer i Afghanistan}

Blandt de forhold, der vil blive givet prioritet i 2009, er styrkelse af donorkoordinationen. Det internationale samfund med FN i spidsen står her over for en helt central udfordring.

Det er stadig vigtigere at styrke koordinationen blandt donorer for dels at sikre øget bistandseffektivitet, dels transparens i forhold til den afghanske regering. Det vil ikke mindst være vigtigt fortsat at styrke FN's koordinerende funktion og bakke denne op med klar politisk opmærksomhed og støtte.

Danmark vil ligeledes i 2009 prioritere et styrket nordisk samarbejde. I relation til udviklingsarbejdet vil Danmark således søge at etablere et fortsat tættere nordisk samarbejde inden for bistandseffektivitet, menneskerettigheder samt støtte til civilsamfundet.

Situationen i Pakistan og i grænseområderne vil også i 2009 have stor betydning for udviklingen i Afghanistan. Fra dansk gives den regionale dimension stor opmærksomhed. Danmark vil i 2009 arbejde for at styrke den internationale indsats på området og ser gerne, at EU påtager sig en større rolle i forhold til Pakistan. EU's Udenrigsministerråd vedtog i december 2008, at styrke EU's relationer med Pakistan med henblik på at støtte den demokratiske regering. EU vil søge at øge den politiske dialog, handelsrelationerne og støtten til de demokratiske institutioner.

Inden for rammerne af Afghanistan-strategien vil Danmark arbejde for, at der gennemføres tiltag, som understøtter samarbejdet mellem Afghanistan og Pakistan - fx jirgaer i grænseområderne med deltagelse af både Afghanistan og Pakistan og andre konfliktløsende initiativer bl.a. med sigte på involvering af kvinder fra de to lande. Dertil kommer en forventet fortsat anvendelse af nærområdemidler til støtte for afghanske flygtninges hjemvenden fra Pakistan

De danske styrker i Afghanistan vil fortsat arbejde på at presse oprørsgrupper væk fra de største befolkningscentre i vores indsatsområde $\mathrm{i}$ Helmand-provinsen fremgår det af den årlige afrapportering fra regeringen, udgivet i marts 2009. Rapporten opsummerer udfordringerne for Danmark hér i 2009.

\section{Sikkerhedsindsatsen}

I 2009 vil både sikrings- og ekskorte- 
opgaver samt stabiliserings- og egentlige kampopgaver fortsat udgøre en væsentlig del af det danske styrkebidrags opgaveportefølje. Overordnet set skal alle operationerne bidrage til at understøtte stabilisering og udvikling af provinsen civilt, herunder politisk, økonomisk og socialt.

Operationerne vil have til hensigt fortsat at presse oprørsgrupperne væk fra de vigtigste befolkningscentre i provinsen samt tilvejebringe en tilstrækkelig grad af bevægelsesfrihed i og imellem befolkningscentrene.

Operationerne skal derved understøtte den civile og politiske indsats, styrke mulighederne for at de afghanske myndigheder samt de traditionelle lokale politiske strukturer (shuraer, ældreråd m.v.) kan virke og samarbejde på lokal-, distrikts- og provinsniveau samt med relevante ministerier i Kabul.

En anden udfordring bliver overtagelsen af ansvaret for et garnisonsOMLT (Operational Mentor and Liaison Team) primo 2009. OMLT'et skal rådgive og vejlede i forhold til en række væsentlige funktioner, der bidrager til den operative drift af en afghansk lejrs faciliteter, herunder indkvartering, uddannelsesstøtte, sanitetsstøtte samt mentorvirksomhed. Dette bidrag vil bestå af 10-15 soldater, og opstilles af Flyvevåbnet.

Som i resten af landet vil sikkerheden i Helmand før, under og mellem valgene i 2009 og 2010 være af stor betydning for Afghanistans sammenhængskraft samt opfattelsen af de afghanske myndigheders og ISAF's evne til at levere sikkerhed til befolkningen. Valget vil være en oplagt lejlighed for oprørsgrupperne til at udfordre de afghanske myndigheders og ISAF's evne til at levere sikkerhed.

\section{EUPOL}

EU's politimission må i 2009 forventes at blive spændt hårdt for, hvis den skal løfte de mange nye opgaver, som indenrigsminister Atmar har betroet EUPOL og Kai Vittrup. I erkendelse af, at missionen i sin nuværende form næppe ville kunne løse alle opgaver, arbejdes der ved udgangen af 2008 for hurtigst muligt at fordoble missionen til 400 politifolk.

Imens forbliver de grundlæggende udfordringer med kapacitetsopbygningen af det afghanske nationale politi (ANP) de samme.

Hvis de internationale aktører bl.a. EU og USA - skal skabe fremskridt på politiområdet, er det nødvendigt at have en både realistisk arbejdsdeling og et endnu tættere samarbejde end det er tilfældet i dag. EUPOL har påtaget sig den ledende rolle i den påkrævede omstrukturering af den enhed, der i dag forestår koordinering på politiområdet.

Fra dansk side vil dette arbejde blive støttet. 


\section{Statsopbygning}

De nært forestående valg udgør både et væsentligt indsatsområde samt en af de største udfordringer for Afghanistan og det danske engagement i 2009. Legitime, frie og retfærdige valg er en forudsætning for konsolideringen af demokratiet i Afghanistan og som sådan vital for befolkningens fortsatte opbakning til den afghanske regering.

Velgennemførte valg vil således udgøre et helt centralt aspekt i at skabe stabilitet og fremskridt i landet. Korruptionsbekæmpelse udgør fortsat en central udfordring. Den reelle politiske vilje i den afghanske regering til at gøre op med den omfattende korruption, der gennemsyrer alle dele af samfundet, er af afgørende betydning.

Trods fremskridt på menneskerettighedsområdet siden Talibans fald, vil der fortsat være et betydeligt behov for indsatser, der gør op med de omfattende menneskerettighedskrænkelser. Ikke mindst ytringsfriheden vil også fremover være under angreb. Træning og beskyttelse af journalister vil derfor stå centralt $\mathrm{i}$ 2009.

\section{Uddannelse}

Støtte til reform af undervisningsministeriet vil være et væsentligt indsatsområde for Danmark også i 2009. Der vil blive givet støtte til yderligere 15 mio. skolebøger. Her- udover vil der blive behov for yderligere at styrke sammenhængen mellem det nationale og det provinsielle niveau - dvs. Helmand for Danmarks vedkommende. Desuden vil det være væsentligt at sikre gennemførelsen af den aftale, der i efteråret 2008 blev indgået om dansk støtte til bygning af ni skoler, to kollegier og finansiering af stipendier.

\section{Forbedrede levevilkår}

NSP og MISFA vil fortsat være de største indsatsområder for dansk bistand i relation til forbedring af levevilkår på nationalt niveau. Det er i den sammenhæng en særlig stor udfordring at sikre den fortsatte udvikling af NSP på en sådan måde, at de lokale udviklingsråd bliver reelt selvstændige og bæredygtige enheder, der også kan fungere efter hensigten, når udbetalinger af bloktilskud stopper. Der er en række initiativer i gang med henblik på udvikling af decentrale strukturer, herunder IDLG (Independent Directorate for Local Governance).

Der mangler imidlertid stadig endelig afklaring af, hvordan de forskellige initiativer skal spille sammen, eksempelvis hvilken rolle de lokale udviklingsråd under NSP vil komme til at spille i forhold til den struktur IDLG lægger frem. Det er vigtigt, at de mange gode resultater opnået under NSP ikke går tabt.

Det vil blive undersøgt om en del af den danske bistand i 2009 skal 
indgå i PRT'ets støtte til genopbygning af vandkraftsanlægget i Gereshk. Bliver det en realitet, vil der ikke blot være tale om en betydelig $\varnothing$ konomisk satsning med potentielt stor virkning på den økonomiske udvikling i området, men det bliver også en vanskelig opgave på grund af de skrøbelige sikkerhedsforhold i Helmand-provinsen.

\section{Nærområdeindsatsen}

I starten af 2009 påbegyndes planlægningen af de næste fire års nærområdeindsats i Afghanistan. I overensstemmelse med nærområdebistandens generelle formål vil fokus fortsat være på bistand til flygtninge og internt fordrevnes varige tilbagevenden og reintegration. Det forventes, at indsatsen samlet vil omfatte et budget på 300 mio. kr., og at aktiviteterne vil blive gennemført gennem et antal partnere, herunder FN organisationer samt danske og internationale NGO'er.

Fra dansk side vil man derudover arbejde for, at FN i sin bistand til hjemvendte flygtninge i højere grad tilstræber, at indkøb af fødevarer sker lokalt for dermed at bidrage til den afghanske økonomi. Også opførelse af huse og dertil knyttet infrastruktur bør i større udstrækning udføres af lokal arbejdskraft.

Endvidere vil Danmark nøje følge den fortsatte tilbagevenden af flygtninge fra Iran og Pakistan, idet der er tegn på stigende problemer ved reintegration, hvilket bl.a. viser sig $\mathrm{i}$ et voksende antal internt fordrevne $\mathrm{i}$ Afghanistan.

\section{Fødevarekrisen}

På den humanitære front vil opmærksomheden i særlig grad være fokuseret på den fortsatte fødevarekrise i dele af Afghanistan, specielt hvad angår perioden frem til næste høst i sommeren 2009. Fortsætter den nuværende tørke i det kommende år, må det internationale samfund yderligere styrke den humanitære indsats.

KILDE: Udenrigsministeriet 2009: Den danske indsats i Afghanistan 20082012. Afrapportering 2008 www.um.dk 